\title{
Characteristics of a European Beaver Population in the Suwalki Lakeland ${ }^{1}$
}

\author{
Wirgiliusz ZUUROWSKI \& Bogdan KASPERCZYK
}

\begin{abstract}
Zurowski W. \& Kasperczyk B., 1986: Characteristics of a European beaver population in the Suwalki Lakeland. Acta theriol. 31, 24: 311-325 [With 4 Tables \& 3 Figs]

In the autumn-spring seasons of $1976-77$ and $1984-85$, an inventory of beaver sites was made in the Suwalki Lakeland. The respective numbers of the sites recorded were 137 and 257. The increase in the number of sites was due to their higher density in the earlier occupied areas and to the expansion of beavers westwards and southwards. The most preferred habitats of beavers were lakes and rivers (1976-77: lakes $43 \%$, rivers $47 \% ; 1984-85$ : lakes $49 \%$, rivers $38 \%$ ). Females produced 1.7 young per litter, and $68 \%$ of pairs reproduced. In $1977-85$, 217 beavers were captured in the Suwalki Lakeland. It has been fourid that a high proportion $(56 \%)$ of beavers had black hair, females slightly outnumbered males $(54: 46)$, and the proportion of adults was high in the population. Adult females were heavier than adult males. Young beavers gained weight during their first winter, whereas the weight of adults decreased during winter. The beaver population of the Suwałki Lakeland enters a stable phase, and soon an annual reduction of animal numbers will be needed.
\end{abstract}

[Research Station, Polish Acad. Sci., Popielno, 12-222 Wejsuny]

\section{INTRODUCTION}

There are no literature data on the occurrence of beavers in the Suwałki Lakeland in 18th and 19th centuries. It seems, however, that beavers inhabited this region permanently or temporarily as it may be inferred from many notes on beaver occurrence in the basins of Pregola and Niemen, several tributaries of which have their sources in the Suwalki Lakeland. In the 18th and early in the 19th centuries, there were many sites of beaver in the Prussian Lowland, Mazurian Lakeland, Polesie, Wolyn, and Podole. In the second half of the 19th century, also black beavers were abundant on the Niemen river (Janota, 1876; Linstow, 1908).

In 1918, beavers on the Niemen river and on the tributaries of the Prypec river were within the boundaries of the restituted Poland. These beavers were protected by law from 1919, and by 1939 their stock

1 Praca wykonana $w$ ramach problemu MR-II-19 koordynowanego przez SGGW-AR w Warszawie. 
reached about 400 individuals. A site nearest to our present boundaries was at the confluence of Czarna Hańcza and Niemen (Dehnel, 1948). In September, 1944, beavers appeared in the basin of the Marycha river in the administrative districts of Punsk and Krasnopol, and probably also the Czarna Hańcza river near lake Wigry (Źurowski, 1983). They gave rise to a sound beaver population in the boundaries of Poland delimited after 1945 .

In 1955, Russians introduced 40 beavers into the Pregola basin and 30 beavers into the Szeszupa basin (Žarkov, 1969). This resulted in an expansion of beavers into north-eastern border regions of Poland, including the Suwałki Lakeland, since the 1960s. The Suwałki beaver population rapidly extended its range to the upper parts of the Goldapia, Błędzianka, Bludzianka, Pissa, and Szeszupa basins. In 1949, after an introduction of several beaver pairs from Woronezh to old canals of the fortress Osowiec, a beaver population on the river Biebrza was established (Dehnel, 1958). Presumably, beavers emigrating from this population also reached the Suwałki Lakeland through the Augustów canal, upper Biebrza, and the Wołkuszanka river.

The aim of this paper is to characterize the beaver population of the Suwałki Lakeland, and the changes occuring in this population over an eight-year period. The analysis involved changes in number of beavers, their spatial distribution, habitat preference, reproduction, and population structure.

\section{STUDY AREA, MATERIAL, AND METHODS}

The study object was a beaver population inhabiting the Suwalki Lakeland, thus a part of the Biebrza valley along the line Augustów-Lipsk to the south $\left(54^{\circ} 47^{\prime} 30^{\prime \prime} \mathrm{N}\right)$, and Szerskie Hills to the west $\left(22^{\circ} 30^{\prime} \mathrm{E}\right)$. From the north and east, the study area was delimited by the state boundary (Fig. 1). The Suwalki Lakeland, together with the Augustów Plain, form an extention of the Mazurian Lakeland. They are crossed by watersheds of Pregola, Niemen, and Narew. These area was shaped by several advances and retreats of glaciers. Gently rolling hills are dissected by river walleys and lakes. Three longitudinal hill ranges $180-220 \mathrm{~m}$ high above sea level from watersheds. Almost $3,4 \%$ of this area is covered with water. In addition to rivers, this area is dotted with 250 lakes more than 1 ha in surface area, 200 small lakes, and numerous marshes. A characteristic feature of this region is the location of lakes at very different levels. For example, lake Wigry is $132 \mathrm{~m}$ above sea level, Hańcza $227 \mathrm{~m}$, and Wiżajny $243 \mathrm{~m}$.

Water situation in this region determines the development of the beavers population, which is made up of animals differing in their origin. The bulk of the population consists of beaver native to the Niemen basin, which spontaneously colonized this area. In 1955, beavers from the north were introduced there (Zarkov, 1969). They presumably come from the Niemen population too as they were captured in Byelorussia. Beavers immigrating from the south are descendants of the 
animals from Woronezh, introduced in old canals of the fortress Osowiec in 1948 (Dehnel, 1958).

The first inventory of beaver sites was made by workers of the Research Station PAS at Popielno in the autumn-spring season of 1976/77. Active sites (with families) were located, also the type of habitat and the type of family nest were noted. From 1978/79, annual inventories were made by the forest service according to the instruction prepared at the Research Station PAS at Popielno. The results were mapped using a grid of $5^{\prime}$ longitude and $2.5^{\prime}$ latitude. This grid was obtained from the grid used in the Polish Red Book by dividing the smallest squares into four equal parts. The surface area of each square is about $25 \mathbf{~ k m}^{2}$.

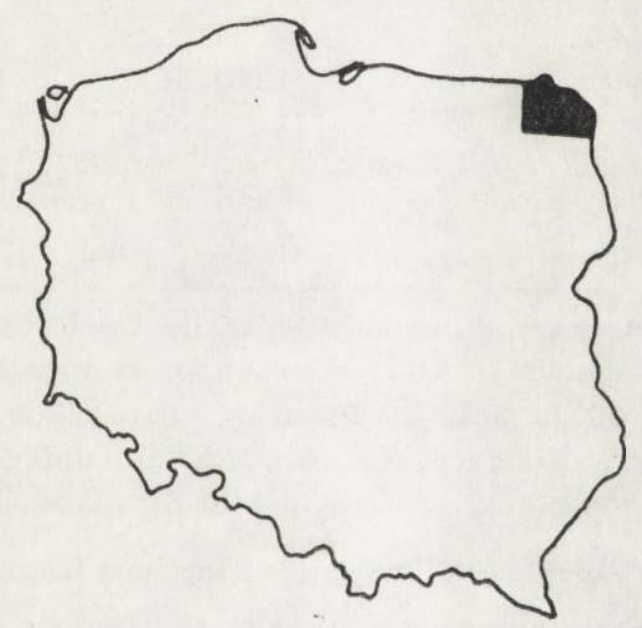

Fig. 1. Location of the study area in relation to the state boundaries of Poland.

When calculating population density, it was assumed that beavers occupied whole squares in which at least one site was recorded.

Using dogs, nets, and traps set at burrow entrances, beavers were captured twice a year, in the first half of April and in the first half of October from 1977 to 1985 (Zurowski, 1979). Both captured and fleeing beavers were counted. Notes were taken of the colour of their fur, also sex and body weight for the captured animals. Body weight and appearance were used to estimate age. The Student t-test was used to estimate the significance of differences between males and females for different seasons.

Using $0.5 \mathrm{~h}$ tape recording, the birth of young beavers was monitored in about 15 beaver lodges, in 1978-85, each year during May and the first 10-day period of June (Zurowski, 1979).

\section{RESULTS}

\subsection{Population Growth}

The inventory made in $1976 / 77$ revealed that the beaver population under study occupied 137 sites, and the inventory in 1984 and 1985 showed 257 sites. Thus, 120 new sites were occupied by beavers during 
eight years (Table 1), accounting for about $8 \%$ annual increase. In fact, however, the rate of population growth was higher, because 217 animals being captured over the same period. Taking this number into account the annual growth rate of beaver sites was about $11 \%$.

Table 1

The number of sites of the European beaver in the Suwalki Lakeland. In parentheses the percentage of all sites.

\begin{tabular}{lrr}
\hline Year of inventory & $1976 / 77$ & $1984 / 85$ \\
\hline Number of beaver's sites & 137 & 257 \\
Beaver works: logdes & $84(61)$ & $128(51)$ \\
& $53(39)$ & $123(49)$ \\
burrows & $7(5)$ & $50(20)$ \\
dams & $59(43)$ & $126(49)$ \\
Habitat: lakes & $65(47)$ & $99(38)$ \\
rivers & $2(2)$ & $12(5)$ \\
drainage channels & $11(8)$ & $20(8)$ \\
others & &
\end{tabular}

The results of the annual inventories made by forest service cannot be utilized in this paper becouse they underestimated the number of beaver sites from 10 to $30 \%$ in different years. This underestimation mostly resulted from the fact that foresters did not count beavers inhabiting running waters and water bodies in farmland.

\subsection{Changes in the Population Range and Density}

The increase in the number of beavers in the study population occured in two ways: through expansion of animals into new areas and due to an increase in density in the areas occupied by 1976/77 (Fig. 2). During
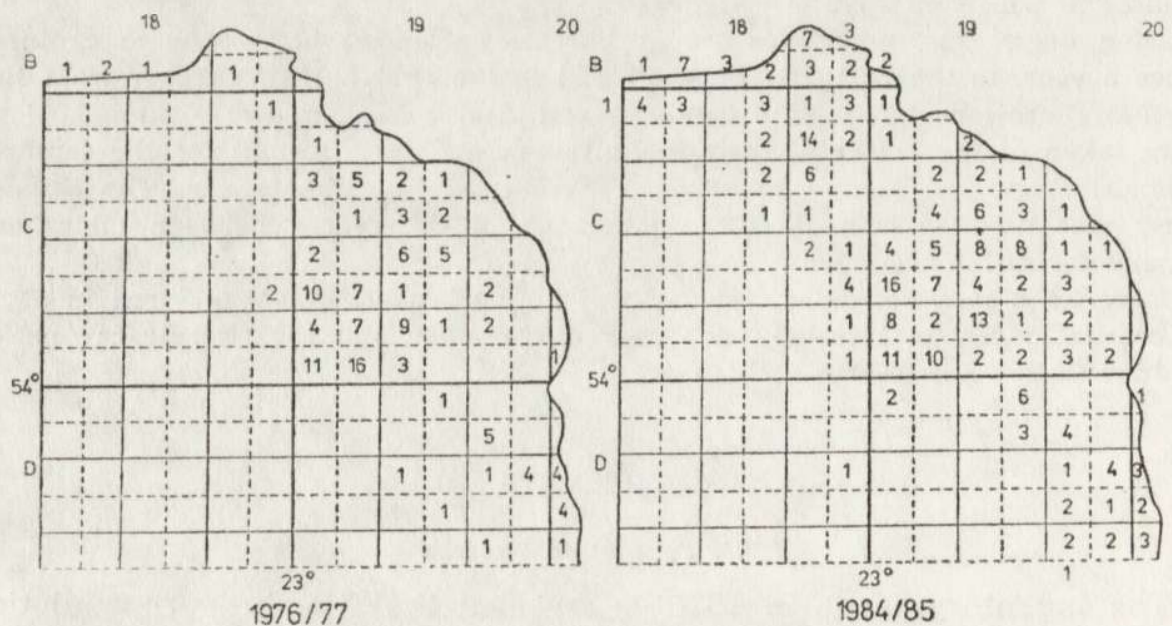

Fig. 2. Distribution and numbers of beavers in the Suwalki Lakeland in $1976 / 77$ 
the first inventory in $1976 / 77$, beavers occupied an area of about 900 $\mathrm{km}^{2}$. Until $1984 / 85$, the area occupied by this population increased to about $1675 \mathrm{~km}^{2}$. This was due to the migration of animals from the central part of the population range to the west and from the northern part to the south. Beavers colonized the upper part of the Czarna Hańcza basin, upper Szeszupa river, and upper tributaries of the Pregola river, that is, Żytkiejmska Brook, Błędzianka, and Gołdapia.

In $1976 / 77$, beavers occured in 40 squares of the grid on 137 sites, and in 1984/85, 165 beaver sites were recorded in the same area. In 19 squares, the number of sites increased, in 10 squares it did not change, and in $1984 / 85$ it increased to 18.3 per $100 \mathrm{~km}^{2}$ of the same area. On that disappeared. In $1976 / 77$, the density of sites was 15.2 per $100 \mathrm{~km}^{2}$, and in $1984 / 85$ it increased to 18.3 per $100 \mathrm{~km}^{2}$ of the same area. on the newly colonized area, beavers were recorded in 40 squares and 92 sites. The density of sites was 11.9 per $100 \mathrm{~km}^{2}$. The mean density of sites on the entire beaver range in the Suwałki Lakeland in 1984/85 was 15.3 per $100 \mathrm{~km}^{2}$.

The list of sites recorded during the inventory in 1976/77 was published earlier (Pucek \& Żurowski, 1983). A complete list of beaver sites in the Suwałki Lakeland in 1984/85 is in Appendix 1.

\subsection{Habitats Occupied by Beavers}

During eight years, the proportion of beaver sites increased on lakes (from 43 to $49 \%$ ) and drainage channels (from 2 to $5 \%$ ), whereas it decreased on rivers (from 47 to $38 \%$ ) (Table 1). These shift in habitats occupied accounted for changes in the form of nests built by beavers. In $1984 / 85$, they lived in burrows more frequently than in 1976/77. They also constructed dams much more frequently (Table 1).

It has been found that foraging conditions (browsing in winter) deteriorated over eight years, willow trees and birches being less abundant on the shores.

\subsection{The Number of Beavers per Site}

In 102 sites, 297 beavers were either captured or only observed when fleeing. The animals were captured mostly in young sites, thus usually without typical family groups made up of the parental pair and offspring from succesive two years. The sites with such complete family groups accounted for only $17 \%$ of the captured sites. There were 92 beavers recorded in these sites, that is, 5.5 individuals pere site on an average. Beavers from such sites are difficult to capture in an active way, and in some cases it is not possible to capture them at all because they have 
a complex system of burrows, channels, and outlets. Young sites were inhabited by 2.4 individuals on an average. In 1984/85, the proportion between young and old multiannual sites was examined in the Wiżajny administrative district. Out of 14 active sites, six (44\%) were old with complete families. Using the results of trapping and observations of the number of animals in each site during trapping, and also the known proportion of young and old sites, it was possible to estimate the number of beavers per site, which was 3.7 individuals (weighed average).

\subsection{Reproduction, Sex Ratio and Age Structure}

Using tape recording of the live-born young, it was possible to estimate the litter size (Table 2). Over the seven-year study period, 104 sites were surveyed, and in 71 of these sites $(68 \%)$ young beavers were found. There were 120 live-born young, that is, 1.7 young per litter on

Table 2

Litter size as determined by tape recording.

\begin{tabular}{lccccccc}
\hline & \multicolumn{9}{c}{ Littler size } & & \\
Year & 0 & 1 & 2 & 3 & 4 & Average & SD \\
\hline 1978 & 4 & 2 & 6 & 1 & - & 1.9 & 0.60 \\
1979 & - & 4 & 8 & 1 & - & 1.8 & 0.60 \\
1981 & 6 & 6 & 7 & 1 & - & 1.6 & 0.63 \\
1982 & 5 & 1 & 6 & - & 1 & 2.1 & 0.83 \\
1983 & 9 & 7 & 3 & 1 & - & 1.5 & 0.69 \\
1984 & 5 & 3 & 1 & 1 & - & 1.6 & 0.89 \\
1985 & 4 & 6 & 5 & - & - & 1.5 & 0.52 \\
\hline Total & 33 & 29 & 36 & 5 & 1 & 1.7 & 0.67 \\
\hline
\end{tabular}

the average. It has been found in a beaver farm that the highest losses in young occur during parturition and in the first three days of live, and they account for about $15 \%$ of the young born (Źurowski, 1977). Thus, the empirical litter size found in this study and used for calculating the reproductive potential of the population is likely to be underestimated by $15 \%$.

The reproductive potential was calculated according to the Severcov formula (Trojan, 1975):

$$
q=(r+1)^{1 / p j a}
$$

where: $q$-reproductive potential

$$
\begin{aligned}
& r \text { - litter size } \\
& p \text { - time between successive litters } \\
& j \text { - age at first reproduction } \\
& s-\text { sex ratio }
\end{aligned}
$$

1.7 (this paper)

1 year ('̇urowski, 1977)

3 years (Źurowski, 1977)

1:1 (this paper) 
The reproductive potential calculated in this way is 1.4 . As only $68 \%$ of pairs reproduced, the reproductive potential of the population was about 1.3 .

In $1977-85,217$ beavers were captured in the Suwałki Lakeland. Among them there were 100 males and 117 females. This sex ratio did not differ from $1: 1\left(\chi^{2}=1.33,0.1<p<0.25\right)$. The age structure of the captured animals was as follows: 56 beavers $(26 \%)$ in their first year, $45(21 \%)$ in the second year, and $116(53 \%)$ adults three years old or more.

\subsection{For Colour and Body Weight}

Beavers of the study population showed two types of fur colour, recessive black and dominant brown. The captured animals consisted of 122 black and 95 brown beavers.

Sex- and age-related variation in the body weight of beavers captured in 1977-85 are shown in Table 3. Sex-related differences occured only

Table 3

Variation in the body weight of beavers trapped in the Suwałki Lakeland in $1977-85$ in relation to age and sex.

\begin{tabular}{|c|c|c|c|c|c|c|c|c|c|c|}
\hline \multirow[b]{2}{*}{ Age (yrs.) } & \multicolumn{5}{|c|}{ Males } & \multicolumn{5}{|c|}{ Females } \\
\hline & $\mathrm{n}$ & $\min$ & $\max$. & Avg. & $\mathrm{SD}$ & $\mathrm{n}$ & $\min$ & $\max$ & Avg. & SD \\
\hline 0.5 & 14 & 4.0 & 8.5 & 5.9 & 1.45 & 16 & 4.0 & 8.5 & 5.8 & 1.30 \\
\hline 1.0 & 11 & 5.0 & 11.0 & 8.8 & 1.81 & 11 & 7.0 & 10.5 & 9.1 & 0.92 \\
\hline 1.5 & 11 & 8.0 & 17.0 & 13.2 & 2.48 & 14 & 10.0 & 16.5 & 13.0 & 1.79 \\
\hline 2.0 & 6 & 12.0 & 15.0 & 13.3 & 1.03 & 14 & 10.0 & 15.5 & 13.5 & 1.45 \\
\hline Adult: spring & 34 & 14.0 & 26.0 & 18.2 & 2.36 & 31 & 12.5 & 29.0 & 19.6 & 3.50 \\
\hline autumn & 24 & 15.5 & 24.0 & 19.1 & 2.08 & 27 & 15.0 & 24.5 & 20.5 & 2.59 \\
\hline
\end{tabular}

in adults and at a low significance level: in spring $t=1.9,0.05<p<0.1$ and in autumn $t=2.11,0.02<p<0.05$. It has been found that the body weight of young beavers significantly increased during their first winter $(t=8.28, p<0.001)$, whereas the body weight of adults declined in winter $(t=1.73,0.05<p<0.1)$. Beavers two years old did not change their body weight over winter $(t=0.56, p>0.5)$.

\section{DISCUSSION}

The growth rate of the beaver population in the Suwałki Lakeland was similar to that of some populations in the European part of the USSR (Table 4). The pattern of growth of this population suggests that it is already rather maximal but in the phase of expansion during the 
eight study years. It reached the carrying capacity of the habitat in the central part (Fig. 2). An increasing number of new sites in this part were established in less suitable habitats, frequently in agricultural landscape. The proportion of lodges decreased in new sites and the number of dams increased. This implies that beavers were forced to occupy small streams, often with high borders, including drainage channels and also lakes (Table 1). These changes in the distribution of the species were coupled with its increasing association with man. Beavers sites were situated near farm buildings, roads with intens traffic, or recreational places such as camp grounds. An increase in the number of beaver sites on lakes (49\%) was related to the character of surface waters in the Suwałki Lakeland rather than to the preference of beavers for this habitat. In 1976/77, when the population density was lower and beavers had more choice, they were most abundant on rivers $(47 \%)$.

The sites of beaver capture were selected first in the places where their presence interfered with human activity and then in places where

Table 4

Litter size and annual growth rate of beaver population in the USSR and the Suwałki Lakeland.

\begin{tabular}{|c|c|c|c|}
\hline Region & Litter size & $\begin{array}{l}\text { Population } \\
\text { growth rate }\end{array}$ & Reference \\
\hline $\begin{array}{l}\text { Russian SFSR } \\
\text { Oka nature reserve } \\
\text { USSR } \\
\text { Mokša river } \\
\text { Suwałki Lakeland }\end{array}$ & $\begin{array}{c}1.9 \\
\overline{-} \\
\overline{1.7}\end{array}$ & $\begin{array}{c}\overline{-} \\
10-20 \% \\
7-9 \% \\
8-11 \%\end{array}$ & $\begin{array}{l}\text { Danilov \& Kan'shiev, } 1983 \\
\text { Kudrašov, } 1975 \\
\text { Zarkov, 1976 } \\
\text { Borodina, } 1966 \\
\text { this paper }\end{array}$ \\
\hline
\end{tabular}

trapping could be effective. Thus, this was not a random choice. Nontheless, the material collected reliably characterizes many aspects of the population. The high proportion of black beavers noted here is also typical of the population inhabiting the European part of the USSR. Zamachajeva (1970) have found that black beavers account for $34.4 \%$ of the population in the Russian SFSR, for $15.7 \%$ in Byelorussia, and for $45 \%$ in the Voronezh region. Black beavers do not occur in other subspecies of the European beaver living in Europe and Asia. For that reason, the beaver population of the Suwałki Lakeland may be especially valuable to the prospective furriery.

The numerical preponderance of adult animals is worth emphasizing $(53 \%)$. It is higher than in other populations - $41 \%$ on the Elbe river (Heidecke \& Dornbusch, 1978) and $40.9 \%$ on the Mokša river (Borodina, 1966). This suggests that the beaver population in the Suwałki Lakeland approaches stability, its further expansion comes to an end, 
and its aging begins in the places most densely occupied. Also the formation of new pairs when one of the mates was lost, or occupation of vacant places by new pairs provide evidence that this population reached the carrying capacity of the habitat, especially in its central part. It seems that trapping carried out by eight years had little effect on the population. Each year $3-5 \%$ of the population was removed. According to Goloduško (1975), a sustainable annual exploitation of European beavers should be $10 \%$ of the stock. A long-term removal of $12 \%$ per year had a harmful effect on population functioning (Safonov, 1969). Boyce (1981) found that removal reduced the survival of adult Canadian beavers, and accounted for an increase in the proportion of young beavers in the reproducing part of the population. These young beavers did not complete their somatic development and, as a result, the mortality of their offspring was increased. In the absence of removal, the survival of adults increased, the proportion of young taking part in reproduction dropped, and, consequently, the number of young born and their survival increased. Kudrašov (1975) found that removal was followed by a decrease in body weight for all age-classes. Presumably the disturbance to the social structure of the family adversely affected its survival. It seems that the exploitation of the population (reduction in number) cannot be high, and if large predators are lacking, it should perform a selective role. Old animals with reduced reproduction should be removed and also young animals in their first year.

The body weight of adult and six-month-old beavers captured in this study did not differ from the weight of beavers in Oka nature reserve (Kudrašov, 1975), whereas one- and two-year-old beavers were lighter by about $2 \mathrm{~kg}$, presumably because of worse habitat conditons. The basic diet of beavers in the Suwałki Lakeland in winter consisted of willows and birches, and in poorer habitats, alders. The sites with aspen were rare. Owing to trapping in October and April, it was possible to assess the effect of winter on beaver condition. It has been shown that adults loose weight in winter. In view of the results obtained by Aleksiuk et al. (1969), it was somewhat surprising that the youngest group of beavers, 0.5 to 1 year old, gained weight over winter.

An average size of family groups of 3.7 individuals, as calculated for beavers of the Suwałki Lakeland, is generally consistent with the data obtained for other populations: 4 individuals in Lithuania (Palionene, 1975), 4.4 in Belyorussia (Goloduško, 1975), 3.4 in Polesie (Tamuch \& Tolkarev, 1976), and 3.4-4.1 individuals in Oka nature reserve ( $\mathrm{Ku}$ drašov, 1975).

It seems that the annual population control and supplying additional 
food in winter are already needed to maintain the optimum condition and productivity of beavers in the Suwałki Lakeland.

Acknowledgement: We are grateful to the chairman of the Voivodeship Board of the Polish Hunting Association in Suwałki, Jan Goździewski M. Sc., and to Wiesław Radziwiłko and Jan Wolski for their assistance in trapping and material collecting.

\section{REFERENCES}

1. Aleksiuk M. \& Cowan I. M., 1969: Aspects of seasonal energy expenditure in the beaver (Castor canadensis Kuhl) at the northern limit of its distribution. Can. J. Zool., 47: 471-481.

2. Borodina M. N., 1966: Materiały k izučeniju dinamiki mokšanskoj bobrovoj populacii. Tr. Mordovskogo gos. Zap., 3: 5-38.

3. Boyce M. S., 1981: Beaver life-history responses to exploitation. J. appl. Ecol., 18: $749-753$.

4. Danilov P. I. \& Kan'shiev V. Y., 1983: The state of populations and ecological characteristics of European (Castor fiber L.) and Canadian (Castor canadensis Kuhl) beavers in the northwestern USSR. Acta zool. Fenn., 174: 95-97.

5. Dehnel A., 1948: Wykaz stanowisk bobra Castor fiber vistulanus Matschie w dorzeczu górnego i środkowego Niemna oraz górnej Prypeci w latach 1937-1939. Fragm. faun. Mus. zool. pol., 5: 199-224.

6. Dehnel A., 1958: Zamki na wodzie. Państwowe Zakłady Wydawnictw Szkolnych: $1-75$. Warszawa.

7. Goloduško B. Z., 1975: Vlijanie promysla na populacii bobrov. Tr. 2-go Vsesojuz. sov. mlekopit.: 306-309. Moskva.

8. Heidecke D. \& Dornbusch M., 1978: Verbreitung und Okologie, Schutz und Förderung des Elbebibers Castor fiber albicus Matschie, 1907 in der DDR. Arch. Natursch. u. Landschaftsforsch., 18: 151-160.

9. Janota E., 1876: Obrazki z życia zwierząt: bóbr, żubr. Czytelnia Staropolska: 1-76. Kraków.

10. Kudrašov V. S., 1975: O faktorach, regulirujuščich dviženije čislennosti rečnogo bobra v Okskom zapovednike. Tr. Okskogo gos. Zap., 11: 5-124.

11. Linstov O., 1908: Die Verbreitung des Bibers im Quartär. Museum für Natur und Heimatkunde zu Magdeburg, Abhandlungen und Berichte 1(4): 211-387.

12. Palionene A. I., 1975: Sovremennoje sostojanije bobrovych kolonij i perspektivy promysla bobra $\mathrm{v}$ Litovskoj SSR. Tr. Voronez. gos. Zap., 21: 59-60.

13. Pucek Z. \& Zurowski W., 1983: Castor fiber Linnaeus, 1758. [In Pucek Z. \& Raczyński J., eds. "Atlas of Polish mammals"]. Państwowe Wydawnictwo Naukowe: $91-93$ \& 83. Warszawa.

14. Safonov V. G., 1969: Opyt staconarnogo izučenija vlijanija promysla bobra na sostajanije jego poselenij. Tr. Kirov. sel.-chaz. Inst., 21: 16-28.

15. Tatich V. S. \& Tolkačev V. I., 1976: O raspredelenii bobrovych poselenij po nekotorych tipach vodojemov Belorusskogo Polesja. Pripat. Zap.; 142-149. Minsk.

16. Trojan P., 1975: Ekologia ogólna. Państwowe Wydawnictwa Naukowe: 1-419. Warszawa.

17. Zarkov I. V., 1969: Itogi rasselenija reðnych bobrov $\mathrm{v}$ SSSR. Tr. Voronez. gos. Zap., 16: 10-51. 
18. Zarkov O. V., 1976: O strukture naselenija u bobrov. Tr. Voronez. gos. Zap., 21: $91-96$.

19. Zurowski W., 1977: Rozmnażanie się bobrów europejskich w warunkach fermowych. Inst. Gen. Hod. Zwierząt, Rozprawy hab., 7: 1-52. Popielno.

20. Zurowski W., 1979: Preliminary results of European beaver reintroduction in the tributary streams of the Vistula river. Acta theriol., 24: 85-91.

21. Zurowski W., 1983: Rezerwat Ostoja bobrów Stary Folwark. Chrońmy Przyr. ojcz., 39(3): 47-54.

Accepted, February 17, 1986.

Wirgiliusz ŻUROWSKI i Bogdan KASPERCZYK

\section{CHARAKTERYSTYKA POPULACJI BOBRA EUROPEJSKIEGO POJEZIERZA SUWALSKIEGO}

\section{Streszczenie}

W sezonach jesień-wiosna 1976-77 i 1984-85 przeprowadzono inwentaryzację stanowisk bobrów na Pojezierzu Suwalskim. Stwierdzono odpowiednio 137 i 257 stanowisk. Wzrost liczby stanowisk nastąpil w wyniku zwiększenia zagęszczenia stanowisk na terenach wcześniej zajmowanych oraz ekspansję zwierząt w kierunkach zachodnim i poludniowym (Ryc. 3). Najbardziej preferowanymi siedliskami przez bobry były jeziora i rzeki (1976-77: jeziora $43 \%$, rzeki $47 \%$; $1984-85$ jeziora $49 \%$, rzeki $38 \%$ ) (Tabela 1). Plenność samic wynosiła 1.7 mlodego w miocie, a w rozrodzie brało udział $68 \%$ par. W latach $1977-85$ odłowiono na terenie Pojezierza Suwalskiego 217 bobrów. Stwierdzono wysoki odsetek bobrów czarno umaszczonych $(56 \%)$, niewielką przewagę samic nad samcami (54:46) oraz duży udział dorosłych zwierząt $\mathrm{w}$ badanej populacji. Dorosłe samice były cięższe od samców (Tabela 3). Stwierdzono, że mlode bobry podczas pierwszej zimy przyrastały na wadze, a u dorosłych zwierząt występował spadek masy ciała w ciągu zimy. Populacja bobrów Pojezierza Suwalskiego jest $w$ fazie stabilizowania się i w najbliższym czasie będzie wymagać stosowania corocznej redukcji liczebności.

10 - Acta therlologica 


\section{APPENDIX 1}

\section{INVENTORY OF THE SITES OF THE EUROPEAN BEAVER CASTOR FIBER LINNAEUS, 1758 IN THE SUWAEKI LAKELAND IN 1984/85.}

This appendix contains a list of all beaver sites recorded in 1984 and 1985 . These sites are coded according to the geographical grid used here (Fig. 3) and assigned to individual $25-\mathrm{km}^{2}$ squarea.

In parentheses at each site there is information on the type of beaver works (L-logde, B-burrow, D-dam) and the number of sites if more than one. Abbreviations: r. - river, 1. - lake, p. - pond, compt. - forest comparment, FAU forest administrative unit.

\section{LIST OF SITES}

B18 j3 Bludzianka r., compt. 19, 20 (L, D)

j4 Bludzianka r., compt. 135, 136 (B); Bludzianka r., compt. 74, 75 (L, D); Zausze Duży p. (L, D); Żytkiejmska brook, FAU Bludzie (L, D, 4)

k3 Żytkiejmska brook, FAU Malwie (L, D, 2); Lenkupie (L)

k4 Ingiel 1. (L); Bolcie 1. (B)

11 Dunajewo 1. (L); Wiżajny 1., western shore near village Burniszki (L); In forest north of Wiżajny 1. (L); Wiżajny 1., island in northern part of lake (L); Kuprelek 1. (L); Purdel 1. (L); Sudawskie 1. (L)

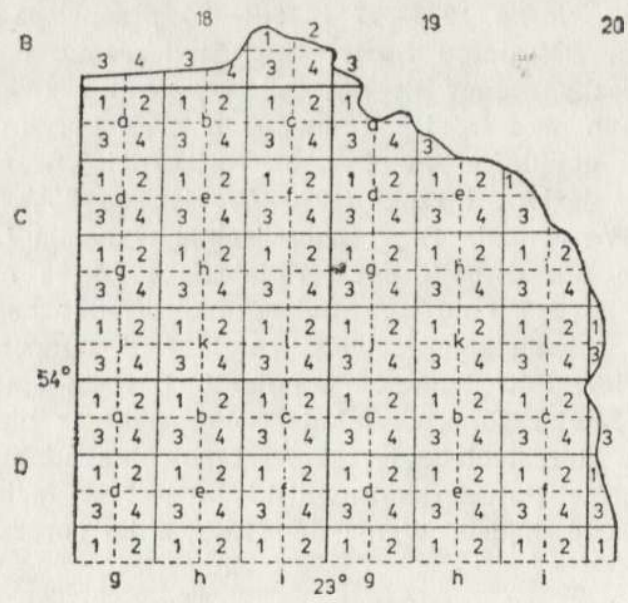

Fig. 3. Symbols used on the map of the distribution of beavers in the Suwalki Lakeland.

12 Skombobole (L); Sudawskie, Księdzowskie Marsh (L, D); Graużyny 1. (L) 13 Marsh near Stanieluszki 1. (L); Wistuć 1. (L); Rogożajny (B)

14 Poszeszupie, drainage channel (L); Potop 1. (L)

B19 j3 Wigra r., at outlet to Szeszupa r. (L); Szeszupa r., at the state border C17 c2 FAU Hajnówka, drainage channel, compt. 95, 96, 155 (L, D)

C18 a1 FAU Dubienniki, drainage channel compt. 201, 281 (L, D); FAU Dubien- 
niki, drainage channel, compt. 256 (L, D); Bludzianka r., compt. 193 (B, D); Bludzianka r. compt. 250 (B, D)

a2 Błędzianka r., compt. 401, 402 (L, D); Błędzianka r., compt. 190, 246 (B); Błędzianka r., compt. 140, 247 (L, D)

b2 Pobłędzie 1. (L); Mauda 1., western shore (L); Mauda 1., eastern shore (L) b4 Bocznel 1. (B, 2)

c1 Czarna Hańcza r., Dziadówek (B)

c2 Szeszupa r., Podstawelek (L); Szeszupa r., Pobondzie (L); Szeszupa r., Rutka-Tartak (B)

c3 Łopuchowo, marsh in farmland (B); Uzdziejek 1. (B); Gulbin 1. (B, 2); Kameduł 1. (B, 2); Jaczno 1. (B, 2); Łuśmin 1. (B); settlement Jaczno (B, D); Cisówek 1. (B); Szeszupa r., Kleszczewek (B); Okrągle 1. (B), Uzdziejek, mill-pond (B)

c4 Krejwelek 1. (B); Przechodnie 1. (B)

e2 Turtul p. (B); Czarna Hańcza r., Rutka (L)

e4 Czarna Hańcza r., Pawłówka (L)

f1 Wodziłki 1. (B); Wodziłki, marsh in farmland (B, D); Szurpiły 1. (B, 2); Jegłówek 1. (B); Kopane 1. (L)

f3 Czarna Hańcza r., Okrągłe (L)

i1 Czarna Hańcza r., Czarnakowizna (B); Czarna Hańcza r., Potasznia (B)

i2 FAU Białorogi, source of Kamionka r. (D)

i4 Okuniowczyk 1. (L); Dąbrówka 1. (L); Czarna Hańczal r., Suwałki (L, B, 2)

12 Suwalki, forest range Sianożęć (L, D)

14 Staw 1. (B)

C19 a1 Small stream joining Jugiel 1. to Szelmentka r. (L);

a3 Szelmentka r., Becejły (B)

b3 Punia 1.; Wolyńce, drainage channels

d2 Meldzine 1.; Bobróczek 1. (L)

d4 Kaletnik-Pokomsze, peat bog (L); Kaletnik-Wiatroluża, peat bog (L, 2); Szlinokiejmie, marsh near brigde on Marycha r. (L)

e1 Kompocie 1. (B); Sejwy 1. (L)

e2 Peiele 1. (L)

e3 Czarna r., section Boksze 1. - Smolany (B, D); Boksze 1. (L); Czarna r., below Smolany (B, D); Czarna r., Krucieniszki (B); Czarna r., Rudawka (B, D); Czarna r., Boksze Nowe (B)

e4 Szejpiszki 1., western shore (B); Ochotniki 1. (B, D); Żwikiele 1. (B)

f3 Gaładuś 1., between villages Radziucie and Jaronajcie (L)

g1 Zielone 1. near Szwajcaria (L); Wiatrołuża r., compt. 97 (B, D); Maniówka r. (B); Dębowo, peat bog (B)

g2 Wiatroluża r., compt. 93 (B); Wiatrołuża, marsh, compt. 87 (L); Jegliniec 1., marsh at western shore (B); Jegliniec 1., eastern shore (B); Czarna Buchta, peat excavation, compt. 265 (B)

g3 Krzywe 1., island (L); Narrows joining Krzywe 1. to Zielone 1. (L); Czarne 1. (L); Koleśne 1. (L); Samle 1. (B); Huta 1. (L); Krzywe 1., north of brigde (L); Królówek 1. (L); Wiatrołuża r., compt. 104 (B); Kamionka r., Okuniowiec (B); Krzywe 1., southern shore (L); Kamionka r., compt. 136 (B); Kolim 1., (L); Przetuczek 1. (L); Samlanka r. (B, D); Gałęziste 1. (B)

g4 Omółówek 1. (L); Remieńkiń 1. (L); Zubronajcie 1. (B); Zubrowo 1. (L); Ryżówka, marsh north of the village (L); Zubrówka r., Zubrówka (L); Dowcień 1. (L)

h1 Gremzdel 1., northern part (L); Gremzdel 1., southern part (L); Bocznel 1., 
northern part (L); Bocznel 1., southern part (L); Czarna r., Murowany Most (B); Czarna r., below Murowany Most (B, D); Czarna r. nature reserve $(\mathrm{L}, \mathrm{B}, 2)$

h2 Czarna r., nature reserve (B, D); Marycha r., Michnowce (B); Szejpiszki 1., southern part (B); Marycha r., State Farm Klejwy (B); Marycha r., at outlet to Sejny 1. (B); Czarna r., Michnowce (B, D); Pawłówka r., compt. 312 (B); Marycha r., Romanowce (B)

h3 Długie 1., north-western part (L); Dlugie 1., southern part (L); Dlugie 1., western shore (B); Gremzdy 1., outlet of stream from Dlugie 1. (B, D)

h4 Epidemia, marsh in forest (B, D); Pawłówka r., Pawłówka (B, D)

il Gawieniańskie 1. (L)

i2 Holny 1. (L)

i3 Sejny 1. (L); Marycha r., section Sejny - Posejenka (B, 2)

j1 Czarna Hańcza r., Sobolewo (B); Compt. 176, drainage channel (L); Czarna Hańcza r., compt. 190 (L); Czarna Hańcza r., compt. 173 (L); Czarna Hańcza r., compt. 203 (L); Wigry 1., compt. 209 (B); Wigry 1., Cimochowizna (L.); Leszczewek 1. (L)

j2 Wigry 1., compt. 233 (L); Czarna Hańcza r., Burdeniszki (L)

j3 Sucharek I 1. (L); Sucharek III 1. (L); Sucharek IV 1., compt. 238 (L); Sucharek IV 1., compt. 221 (B); Sucharek V 1. (B); Muliczne 1. (L); Długie 1. (L); Wigry 1., between settlement Powały and Płociczno (L); Wigry 1., outlet to Okrągłe 1. (B); Wigry 1., island Ostrów (L); Wigry 1., island Ordow (L)

j4 Białe 1. (L); Wigry 1., peninsula Łapa (B); Wigry 1., Czerwony Krzyż (L); Wigry 1., Krusznik (L); Wygorzelec 1. (L); Stanowisko 1. (L); Wigry 1., island Kamień (L); Jeziorki 1. (B); Klonek 1. (L); Krusznik 1. (L)

k1 Czarna Hańcza r., Maćkowa Ruda (L); Czarna Hańcza r., Maćkowa Ruda, compt. 5 (L); Czarna Hańcza r., Buda Ruska (L); Gremzdy 1., source of Pawłowka r. (L); Gremzdy 1., southern shore (L); Gremzdy 1., Gremzdy Polskie (B); Dechło 1. (B); Gremzdówka r., between Gremzdy 1. and Glurhe 1. (B); Głuche 1. (L); Jurkowo 1. (B); Plaskie 1. (B); Compt. 104, drainage channel (B); Miałkie 1. (B)

k2 Karolinek 1. (L)

k3 Czarna Hańcza r., Wysoki Most (B); Czarna Hańcza r., Studzieniczny Las (B)

k4 Czarna Hańcza r., compt. 295 (L); Pogorzelec 1. (B)

11 Marycha r., section Posejnele - Giby (B, 2)

13 Wierśnianka r., compt. 447 (L); Wierśnianka r., compt. 416 (L); Wiłkokuk 1. (B)

14 Marycha r., outlet from Pomorze 1. (B); Small stream joining Zelwa 1. to Wilkokuk 1 . (L, D)

D18 f2 Blizna r., Szczebra (B)

D19 a1 Wigry 1., Bryzgiel (L); Wigry 1., island Walendziaka (L)

b2 Chylinki 1. (L); Czarna Hańcza r., compt. 457 (L); Czarna Hańcza r., compt. 486 (L); Czarna Hańcza r., compt. 510 (B); Czarna Hańcza r., compt. 456 (L, D); Compt. 426, drainage channel (B, D)

b4 Czarna Hańcza r., compt. 567 (L); Czarna Hańcza r., compt. 568 (B); Kalna r. $(\mathrm{L}, \mathrm{D})$ 
c3 Czarna Hańcza r., compt. 841 (B, D); Czarna Hańcza r., compt. 883 (B, D);

Krywelanka r. (B, D); Compt. 941, 840, drainage channel (B, D) f1 Kruglak 1. (B)

f2 Slepe 1. (L); Czarna Hańcza r., compt. 985 (B); Czarna Hańcza r., compt. 964 (B); Szlamica r., Rygol (B)

f3 Maleszówka r. (B, D, 2)

f4 Pieciówka r. (B, D)

i2 Wołkuszanka r., section Rubcewo - Wolkusz (B, D, 2)

i3 Skiblewo, drainage channel (B, D)

D20 a1 Marycha r., compt. 1005, 1024 (B)

a3 Forest range Giedź, compt. 1070 (B, D)

d1 Wiązowiec 1. (L); Ditch joining Szlamy 1. to Wiązowiec 1. (L); Augustów canal, Kudrynki (B)

d3 Augustów Canal, Rudawka (B); Wołkuszanka r., state border

g1 Markowy Most, drainage channel (B, D); Wolkuszanka r., section Mlynek. - state border (2) 